\title{
Kartik G. Krishnan: An illustrated handbook of flap-raising techniques
}

\section{Thieme Verlag, New York, Stuttgart, 2008, 290 pp., 250 figs, Hardcover, Euro (D) 79,95 CHF 133,00, ISBN: 978-3-13-147761-3}

\section{Pierre Kehr}

Received: 15 August 2009 / Accepted: 18 August 2009 / Published online: 2 September 2009

(C) Springer-Verlag 2009

It acts above all as a practical book, primarily treating large scraps of the upper limbs and inferior. This book is far from being exhaustive, and one regrets the absence of the scraps of the hand. It is very interesting with its dimensions practices and didactic, in particular many drawings and a very clear text.
A book to be proposed to those surgeons eager to familiarize themselves with a type of flap and easily being able to apply into the operating theatre.

No funds were received in support of this study.

Alain Graftiaux Strasbourg

P. Kehr $(\square)$

ArgoSpine, Strasbourg, France

e-mail: kehrpier@aol.com 